\title{
Impact of irrigation during flowering and fruit growth on fruit yield and quality of the cactus Opuntia spp.
}

\author{
Mohamed ARBA ${ }^{1 *}$, André FALISSE ${ }^{2,3}$, Redouane CHOUKR-ALLAH ${ }^{1}$ and Marianne SINDIC ${ }^{4}$
}

Received August 27, 2020; accepted March 26, 2021.

Delo je prispelo 27 avgusta 2020, sprejeto 26. marca 2021.

\begin{abstract}
Impact of irrigation during flowering and fruit growth on fruit yield and quality of the cactus Opuntia spp.

Abstract: Most plantations of cactus pear are not irrigated in Morocco and fruits are tiny. The impacts of irrigation during flowering (FLO) and fruit growth (FRG) on fruit yield and quality were monitored along two years on three varieties of cactus pear. In 2011, irrigation treatments were: T1 $(0 \mathrm{~mm}), \mathrm{T} 2$ (30 mm during FLO and $30 \mathrm{~mm}$ during FRG) and T3 $(30 \mathrm{~mm}$ during FRG only). In 2012, irrigation treatments increased to $60 \mathrm{~mm}$ during FLO and FRG. The irrigation treatments were applied in 8 (T3) or 16 (T2) watering, once every three days. Interactions between varieties and treatments were significant for fruit yields and for yield components. In 2011, T2 and T3 irrigations had a negative effect on 'Aissa' and 'Moussa' (-2.8 kg/ plant) and T2 had a positive effect on 'Achefri' $(+2.7 \mathrm{~kg} / \mathrm{plant})$. Fruit quality was not affected by irrigation. In 2012, all the varieties responded positively to irrigation: 'Achefri' and 'Aissa' yielded very significantly more with T3 (plus $63 \%$ and $30 \%$ resp.) and 'Moussa' with T2 (+30\%). All irrigations increased fruit number and size. Irrigation had no significant effect on the fruit quality or slightly decreased the content of total sugars and titratable acidity.
\end{abstract}

Key words: cactus pear; fruit yield; fruit quality; irrigation; irrigation scheduling.
Vpliv namakanja kaktusov iz rodu Opuntia med cvetenjem in rastjo plodov na njihov pridelek in kakovost

Izvleček: Večina nasadov opuncije v Maroku ni namakanih zaradi česar so njihovi plodovi drobni. Vpliv namakanja med cvetenjem (FLO) in rastjo plodov (FRG) na njihov pridelek in kakovost je bil spremljan $\mathrm{v}$ dveh letih na treh sortah. V letu 2011so bila namakanja naslednja: T1 $(0 \mathrm{~mm}), \mathrm{T} 2$ (30 med cvetenjem in $30 \mathrm{~mm}$ med rastjo plodov) in T3 (30 mm samo med rastjo plodov). V letu 2012 je bilo namakanje povečano na $60 \mathrm{~mm}$ med cvetenjem in med rastjo plodov. Namakanja so bila izvedena v 8 (T3) ali 16 (T2) zalivanjih, enkrat vsake tri dni. Medsebojni vpliv obravnavanj in sort je bil značilen za pridelek plodov in njegove komponente. V letu 2011sta imeli obravnavanji T2 in T3 negativni učinek na sorti 'Aissa' and 'Moussa' $(-2,8 \mathrm{~kg} /$ plant$)$, obravnavanje T2 pa je imelo pozitiven učinek na sorto 'Achefri' (+2,7 kg/plant). Namakanje ni vplivalo na kakovost plodov. V letu 2012 so se vse tri sorte odzvale pozitivno na namakanje, pri čemer sta imeli sorti 'Achefri' in 'Aissa' značilno večji pridelek pri obravnavanju T3 (več kot $63 \%$ in $30 \%$ ), sorta 'Moussa' pa pri obravnavanju T2 (+30\%). Vsa namakanja so povečala število in velikost plodov. Namakanja niso značilno vplivala na kakovost plodov, le neznatno sta ste zmanšali vsebnosti celokupnih sladkorjev in titrabilnih kislin.

Ključne besede: plodovi opuncije; pridelek plodov; kakovost plodov; namakanje; plan namakanja.

\footnotetext{
$1^{*}$ Department of Horticulture, Hassan II Institute of Agronomy and Veterinary Medicine, Horticultural Complex of Agadir, Morocco.The corresponding author: arbamohamed@yahoo.fr R. Choukr-Allah: redouane53@yahoo.fr

2 Crop Production Unit, GemblouxAgro-Bio Tech, Liège University, Belgium. E-mail: falisse_a@hotmail.com

3 Faculty of Agriculture, University of Agricultural Sciences and Veterinary Medicine, Cluj-Napoca, Romania

4 Laboratory of Food Quality and Safety, Gembloux Agro Bio Tech, Liège University, Belgium. E-mail: marianne.sindic@ulg.ac.be
} 


\section{INTRODUCTION}

The prickly pear cactus Opuntia plays an important role in the system of agriculture of arid and semi-arid zones, due to its numerous non-food (forage, pharmaceuticals, cosmetic oil from the seeds and for anti-erosion), and food uses (cladodes as vegetables, fruit, and fruit juice) (Nefzaoui \& Ben Salem, 2000; Le Houérou, 2002; Felker \& Inglese, 2003; Arba, 2009; Inglese, 2010). Cultivated historically in Morocco, the cactus Opuntia is a source of food and feed and of incomes for the rural populations in the arid and semi-arid regions. Cactus pear fruits are appreciated by the consumer for their flavour, taste and dietetic properties.

It occupies an important area of about 150000 ha, but plantations are often poorly managed and usually not irrigated. Recently, high density plantations of cactus pear were established with drip irrigation in South Morocco, notably in the areas of Haouz, Tiznit and Guelmim (Arba et al., 2018). The plant has the reputation of low water demand (Nobel, 2002; Nobel \& Bobich, 2002) and of rarely requiring irrigation in the Mediterranean region (Nobel, 2002; Inglese, 2010). As a crassulacen acid metabolism plant, cactus pear is grown under rainfed conditions in the arid and semi-arid areas where low and erratic rainfall is the main limiting factor for its productivity (Potgiter \& D'Aquino, 2017). In the dry areas of Morocco, the hot summer season can extend over 7 to 8 months without rain (from March-April to October-November). Even if the cactus Opuntia is resistant to drought and its water requirements are low, it is difficult for it to overcome the hot and dry periods in the south part of the Mediterranean region. The cladodes and fruits become dehydrated and the pads are marked by desiccated spots. Fruit yield is low and fruit size is poor. However, irrigation may be required in hot and dry zones in the summer, especially for intensive commercial production as in Mexico, USA, Chile, Italy, South Africa, Morocco, Tunisia (Inglese, 2010). In these areas, an addition of limited amounts of water can improve yields when rainfall fails to be sufficient for the plant growth (Oweis \& Hachum, 2012). Several authors also reported that the productivity of cactus pear in the arid and semi-arid areas can be increased by supplemental irrigation which is a common practice in many countries, such as in Italy (Gugliuzza et al., 2002), Jordan and Morocco (Potgieter \& D'Aquino, 2017) and Mexico (Zegbe \& Serna-Perez, 2018, Zegbe et al., 2019; Zegbe \& Sevin-Palestina, 2020). The amount of rain received during the fruit development period (FDP) of the cactus Opuntia, which extends from the beginning of the formation of floral buds until fruit ripening, influences the mean fresh mass of fruit (Zegbe Dominguez et al., 2015). Felker et al. (2002) also suggested that high rainfall during the last two months of fruit maturation led to an increase in fruit size (calibre) and in the content of pulp. The amount of rain received during the FDP also affects the total soluble solids (TSS) of the fruits (Zegbe Dominguez et al., 2015).

This study aims to evaluate the impacts of complemented irrigation at critical phenological stages, particularly during the flowering and fruit-growth stages, on fruit yield and fruit quality, mainly in terms of calibre and composition.

\section{MATERIAL AND METHODS}

The trials were conducted in the orchard of the experimental station of the Hassan II Institute of Agronomy and Veterinary Medicine, Horticultural Complex of Agadir, Morocco (30 $36^{\prime} \mathrm{N}, 9^{\circ} 36^{\prime} \mathrm{E}$, and $32 \mathrm{~m}$ elevation) (Figure 1). The soil has medium depth and good water retention. It has a sandy silty texture with $19-23 \%$ coarse sand, $30-35 \%$ fine sand, $19-22 \%$ coarse silt, $20-21 \%$ fine silt and 5-7 \% clay. The content in organic matter is low to passable, porosity is $45 \%$, and moisture at field capacity is $30 \%$.

The experiments were on three varieties originated from the Sidi Ifni area, south of Agadir: two spineless varieties 'Aïssa' and 'Moussa' of O. ficus-indica L. and one thorny variety 'Achefri' of O. megacantha Salm-Dyck (Figure 2). The plants were planted in 1997 in plots as described hereafter. At the start of the experiment, plantations were fourteen years old, plant size was 2 to $2.5 \mathrm{~m}$ high and each plant had four to five principal branches.

Climatic data relating to rainfall and evapo-transpiration (Figure 3) were obtained from the Saouda Station located $10 \mathrm{~km}$ from the experimental site.

In order to manage correctly the amounts and timing of irrigation, drip irrigation has been installed including flexible perforated pipes at the plant feet and valves, allowing water to pass through for a pre-determined time and water distribution adapted to every single small plot. Details on the scheduled irrigation treatments are presented in Table 1.

The experiment has been set up in an area of 1404 $\mathrm{m}^{2}$. The experimental design was a split-plot with four replicates (4 blocks of $350 \mathrm{~m}^{2}$ ) (Figure 4 ). The variety factor was the main plots ( 3 rows at $3 \mathrm{~m}$ inter-rows $\mathrm{x} 8$ plants at $1 \mathrm{~m}$ distance plus $2 \mathrm{~m}$ paths), area $90 \mathrm{~m}^{2}$, and the irrigation factor, the subplot (one row $8 \mathrm{~m}$ of plantation $\mathrm{x}$ $3 \mathrm{~m}$ inter-row). 


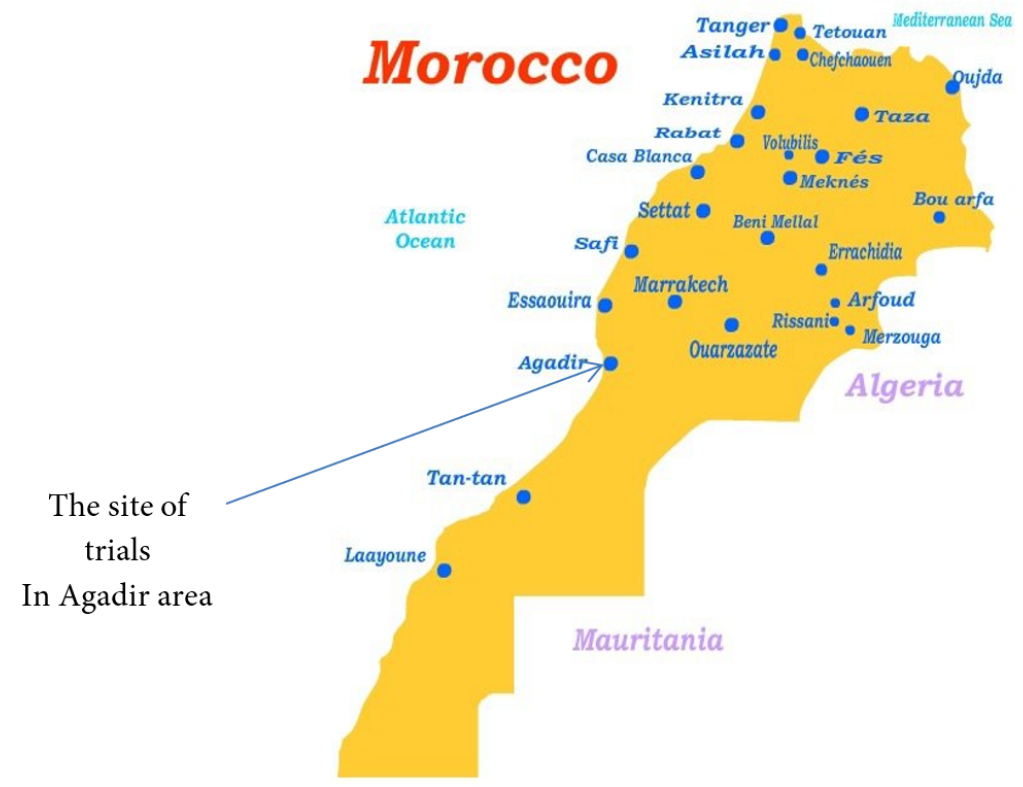

Figure 1: Trials site location in Agadir area within the map of Morocco.

Figure 2:

Opuntia spp. varieties used in the study. Photos were taken in the orchard of the experimental station of the Hassan II Institute of Agronomy and Veterinary Medicine, Horticultural Complex of Agadir, during the ripening phase in July 2011.

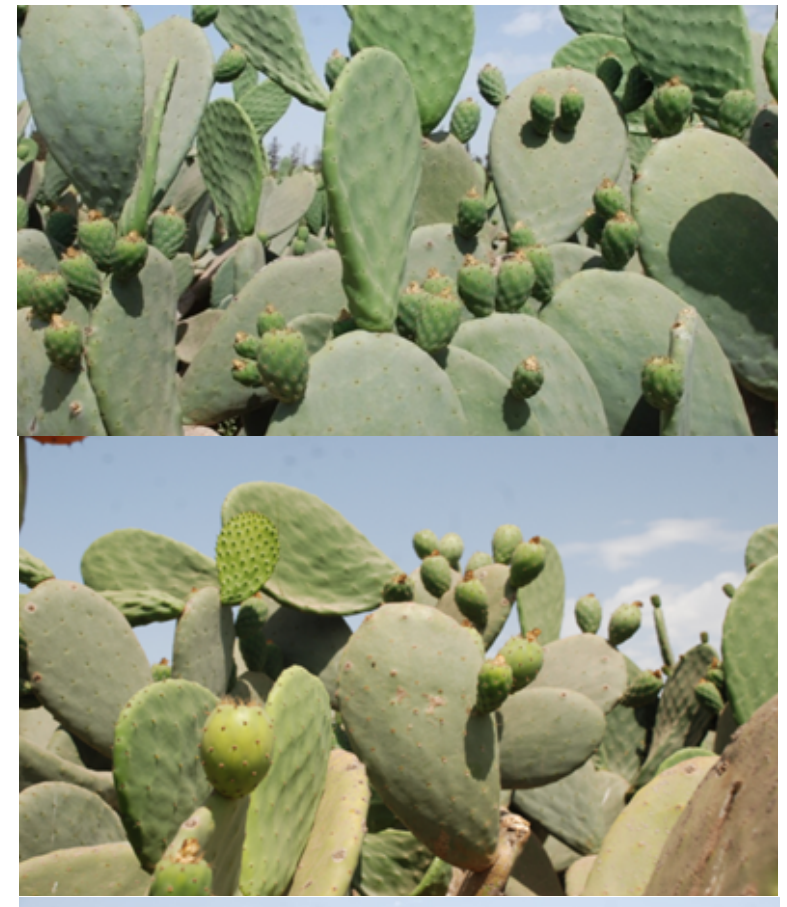

O. ficus-indica 'Aissa'.

O. ficus-indica 'Moussa'.

O. megacantha 'Achefri'. 


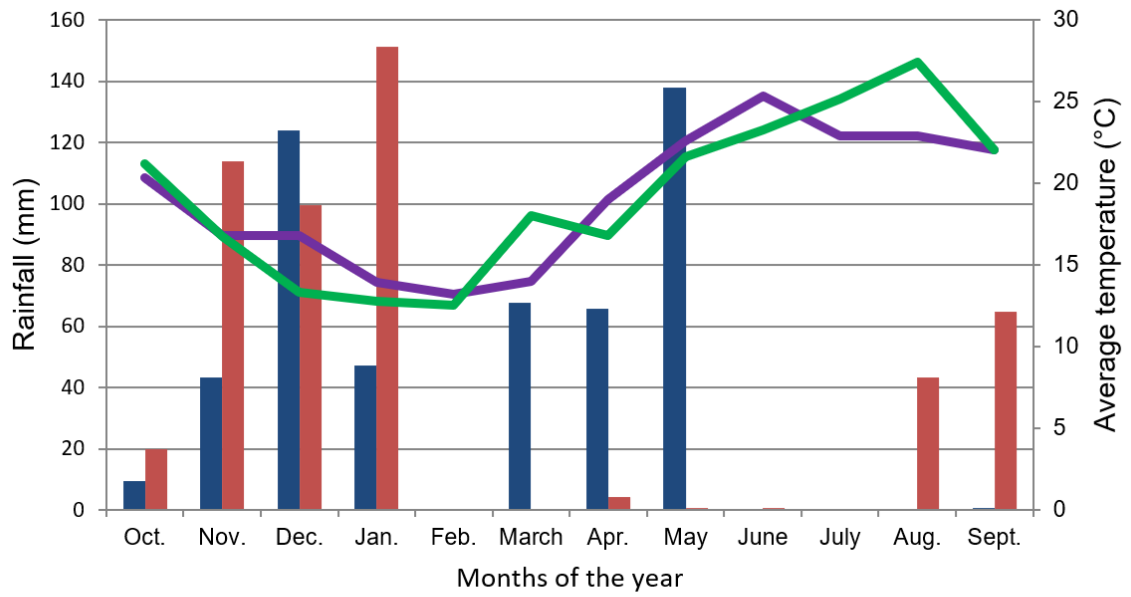

$\begin{array}{ll}\text { Rainfall 2010-2011 } & \text { Rainfall 2011-2012 } \\ \text { Average temp 2010-2011 } & \text { Average temp 2011-2012 }\end{array}$

Figure 3: Average monthly rainfall and air temperature for the study site Agadir, Morocco during the two seasons of study (20102011 and 2011-2012).

Table1: Treatments of irrigation applied during the two years of experiments (2011 and 2012), number of irrigations per treatment and amounts of water per irrigation.

Treatments of irrigation, irrigation frequency, number of irrigations and amount of water per irrigation

\begin{tabular}{|c|c|c|c|c|}
\hline \multirow[t]{7}{*}{$\begin{array}{l}\text { T1 } \\
\text { Control } \\
\text { without } \\
\text { irrigation }\end{array}$} & \multicolumn{2}{|c|}{$\begin{array}{l}\mathrm{T} 2 \\
30 \mathrm{~mm} \text { during flowering (mid-April) }\left(60^{\star} \text { at }\right. \\
\text { end February) }+30 \mathrm{~mm} \text { during fruit growth } \\
\text { (mid-June) }\left(60^{\star} \text { during may) }\right.\end{array}$} & \multicolumn{2}{|c|}{$\begin{array}{c}\mathrm{T} 3 \\
30 \mathrm{~mm} \text { only during fruit growth (mid-June) } \\
\left(60^{*} \text { during May }\right)\end{array}$} \\
\hline & \multicolumn{4}{|c|}{ Irrigation frequency: every third day } \\
\hline & $\begin{array}{l}\text { Number of } \\
\text { irrigations }\end{array}$ & $\begin{array}{l}\text { Amount of water per } \\
\text { irrigation (mm water) }\end{array}$ & $\begin{array}{l}\text { Number of } \\
\text { irrigations }\end{array}$ & $\begin{array}{l}\text { Amount of water per } \\
\text { irrigation( } \mathrm{mm} \text { water) }\end{array}$ \\
\hline & $7+7$ & 4 & 7 & 4 \\
\hline & $1+1$ & 2 & 1 & 2 \\
\hline & $7+7$ & 8 & 7 & 8 \\
\hline & $1+1$ & 4 & 1 & 4 \\
\hline
\end{tabular}

${ }^{\star}$ Total amount of water in the second year experiments

First year experiments

Second year experiments
Amount of water pe

Number of 


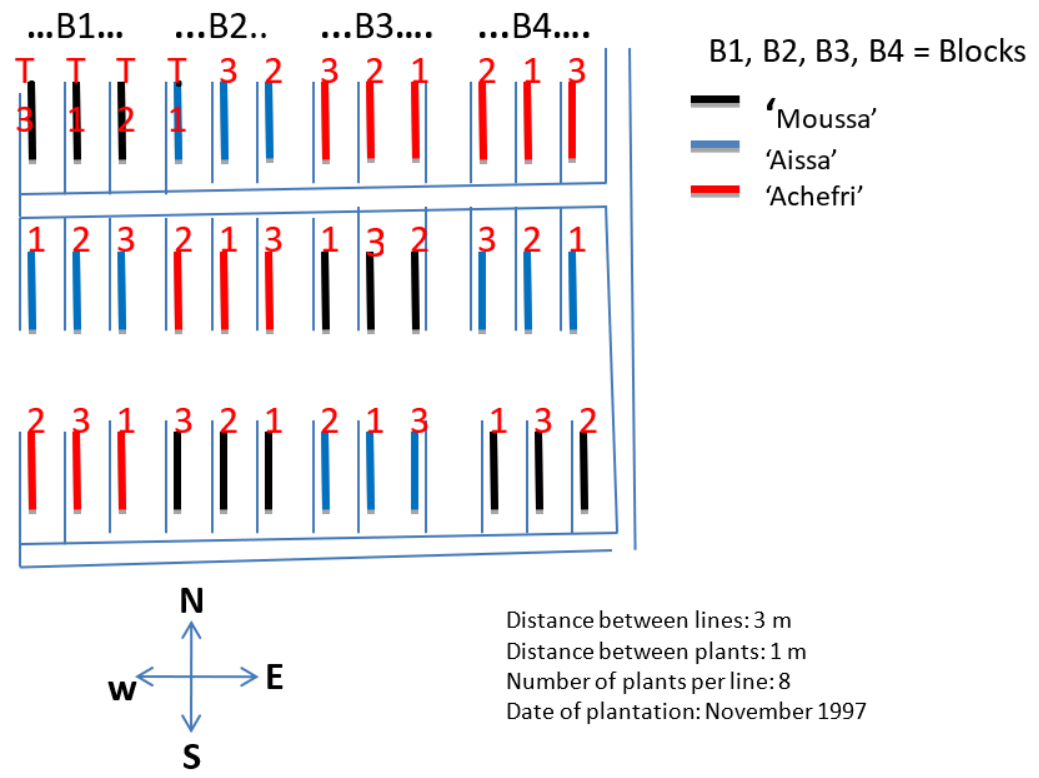

Figure 4: Experimental design in split-plot used in the trials.

Fruit yields expressed as fruit yield per plant were determined by harvesting fruits on two central plants per treatment of irrigation, per variety and per replication. The single fruit average masses have been measured on samples of 20 fruits per plot. The third yield componentfruit number per plant- has been determined by two ways; an 'observed' fruit number on the harvested plants and a "computed" number resulting from the ratio yield/ average fruit mass.

The_following fruit quality_parameters were evaluated: mass, length and diameter, pulp proportion, juice content, as well as fruit organoleptic characteristics, namely amount of juice, titratable acidity, $\mathrm{pH}$, degree Brix, total sugars and juice dry matter. Measurements of the physical characters of fruits were performed on samples of 20 fruits for each treatment and variety. Chessa $\&$ Nieddu (1997) established five size categories for harvested fruits: very small calibre $(<80 \mathrm{~g})$, small (81 to 120 g), medium (121 to $150 \mathrm{~g}$ ), large (151 to $200 \mathrm{~g}$ ) and extralarge (> $200 \mathrm{~g}$ ). Organoleptic properties were determined by chemical analysis of samples of five to six combined fruits per variety in each block (large plots) and per irrigation treatment in a variety (experimental units) (Figure 4). Statistical analyses included ANOVA and Tukey's tests for comparing treatments means.

In order to illustrate the relationship between crop yield and water status, crop water requirements during the two years of the study are presented. Rainfall RAIN and potential evapotranspiration $\mathrm{ET}_{0}$ data displayed by decades were available by the Saouda meteorological sta- tion. To estimate the real evapotranspiration ETR $\left(=\mathrm{Kc}^{*}\right.$ $\mathrm{ET}_{0}$ ), a Kc value for a cactus pear crop has been searched. Attempts to find reliable values of Kc for Opuntia in the region were not successful, despite consulting numerous sources, e.g., Allen et al. (1998), Lazzara \& Rana (2010), Consoli et al. (2013). On the basis of various indications for perennial fruit ligneous plants in the Mediterraneantype environments, a value of 0.7 for Kc has been adopted. Furthermore, it had been assumed that the annual cycle of Opuntia begins immediately at the end of fruit maturation, and thus, in this case, covered the period from 1 October to 30 September (i.e. 36 periods of ten days). In order to simplify, the initial water status (or residual hydrous state at the end of the previous cycle) was not taken into account and rainfall and irrigations during the annual cycle were fully taken into consideration (assuming no losses by run-off or by drainage).

\section{RESULTS AND DISCUSSION}

\subsection{RESULTS}

\subsubsection{Effects of irrigation treatments on fruit yield and physical features in the first year experiments}

Yields of the first year experiments (Table 2) revealed a significant interaction between varieties and irrigations; they indicate the positive effect of irrigation doses on fruit yields for 'Achefri' and no or negative effects on the yields of 'Aissa' and 'Moussa'. 
Table 2: Fruit yields of the varieties Achefri, Aissa and Moussa under the treatments of irrigation T1: not irrigated, T2: $30 \mathrm{~mm}$ during flowering and $30 \mathrm{~mm}$ during fruit growth and T3: $30 \mathrm{~mm}$ only during fruit growth in the $1^{\text {st }}$ year experiments (2011).

\begin{tabular}{cccc}
\hline & \multicolumn{3}{c}{${\text { Fruit yield }\left(\mathrm{kg} \mathrm{plant}^{-1}\right)}$} \\
\cline { 2 - 4 } Variety & $\mathrm{T} 1$ & $\mathrm{~T} 2$ & $\mathrm{~T} 3$ \\
& Not irrigated & $\begin{array}{c}30 \mathrm{~mm}+30 \\
\mathrm{~mm}\end{array}$ & $\begin{array}{c}0 \mathrm{~mm}+30 \\
\mathrm{~mm}\end{array}$ \\
\hline Achefri & $14.6 \pm 0.4$ & $17.3 \pm 0.2^{* *}$ & $15.6 \pm 0.2$ \\
Aissa & $13.4 \pm 0.3$ & $11.3 \pm 0.2^{*}$ & $10.7 \pm 0.4^{* *}$ \\
Moussa & $12.4 \pm 0.4$ & $9.6 \pm 0.3^{* *}$ & $10.8 \pm 0.3^{*}$ \\
\hline
\end{tabular}

interaction: significant ${ }^{*}$ at $p \leq 0.05$; effect variety: ${ }^{*}(p \leq 0.01)$; effect irrigation: not significant.

Table 3: Fruit mass and sizes of Achefri, Aissa and Moussa under the treatments of irrigation T1: not irrigated, T2: $30 \mathrm{~mm}$ during flowering and $30 \mathrm{~mm}$ during fruit growth and T3: $30 \mathrm{~mm}$ only during fruit growth in the first year's experiment.

(a) Fruit mass and pulp mass

\begin{tabular}{|c|c|c|c|c|c|c|c|c|c|c|c|}
\hline & \multicolumn{4}{|c|}{ Fruit mass (g) } & \multicolumn{3}{|c|}{ Pulp mass (g) } & & \multicolumn{3}{|c|}{ Pulp/fruit (\%) } \\
\hline & $\mathrm{T} 1$ & $\mathrm{~T} 2$ & T3 & & $\mathrm{T} 1$ & $\mathrm{~T} 2$ & $\mathrm{~T} 3$ & & $\mathrm{~T} 1$ & $\mathrm{~T} 2$ & $\mathrm{~T} 3$ \\
\hline Achefri & $112 \pm 4 a$ & $122 \pm 3 a$ & $124 \pm 3.5 a$ & ns & $59.3 \pm 2.3 a$ & $66.9 \pm 3 a$ & $67.4 \pm 2.3 \mathrm{a}$ & ns & 53 & 55 & 54 \\
\hline Aissa & $135 \pm 2 b$ & $130 \pm 2 b$ & $129 \pm 2.3 b$ & ns & $72.6 \pm 1.5 \mathrm{a}$ & $68.3 \pm 1.5 \mathrm{a}$ & $69.6 \pm 1.2 \mathrm{a}$ & ns & 54 & 52 & 54 \\
\hline Moussa & $122 \pm 3 a$ & $131 \pm 1.8 \mathrm{a}$ & $130 \pm 2.3 \mathrm{a}$ & ns & $67.2 \pm 1.3 \mathrm{a}$ & $67.8 \pm 1.9 \mathrm{a}$ & $71.7 \pm 1.5 \mathrm{a}$ & ns & 55 & 52 & 55 \\
\hline
\end{tabular}

(b) Fruit length and diameter

\begin{tabular}{ccccccccc} 
& \multicolumn{3}{c}{ Fruit length $(\mathrm{cm})$} & \multicolumn{5}{c}{ Fruit diameter $(\mathrm{cm})$} \\
\cline { 2 - 8 } & $\mathrm{T} 1$ & $\mathrm{~T} 2$ & $\mathrm{~T} 3$ & $\mathrm{~T} 1$ & $\mathrm{~T} 2$ & $\mathrm{~T} 3$ \\
\hline Achefri & $7.17 \pm 0.1 \mathrm{a}$ & $7.40 \pm 0.1 \mathrm{~b}$ & $7.53 \pm 0.1 \mathrm{bc}$ & $*$ & $4.85 \pm 0.06 \mathrm{a}$ & $4.99 \pm 0.06 \mathrm{ab}$ & $5.08 \pm 0.05 \mathrm{~b}$ & $*$ \\
Aissa & $7.24 \pm 0.1 \mathrm{a}$ & $7.09 \pm 0.04 \mathrm{~b}$ & $7.12 \pm 0.05 \mathrm{~b}$ & $*$ & $5.27 \pm 0.04 \mathrm{a}$ & $5.35 \pm 0.04 \mathrm{ab}$ & $5.23 \pm 0.05 \mathrm{a}$ & $*$ \\
Moussa & $7.14 \pm 0.1 \mathrm{a}$ & $7.12 \pm 0.01 \mathrm{a}$ & $7.17 \pm 0.02 \mathrm{~b}$ & $*$ & $5.02 \pm 0.1 \mathrm{a}$ & $5.25 \pm 0.07 \mathrm{~b}$ & $5.28 \pm 0.07 \mathrm{~b}$ & $*$ \\
\hline
\end{tabular}

*: significant difference at $p \leq 0.05$; ns: no significant difference; interaction: a: not significant

For each variety and each variable, different letters a,b,c indicate significant differences 
Table 4: Effect of irrigation treatments T1: not irrigated, T2: $30 \mathrm{~mm}$ during flowering and $30 \mathrm{~mm}$ during fruit growth and T3: 30 $\mathrm{mm}$ only during fruit growth on the number of fruits produced per plant and by 10 cladodes in 2011 .

\begin{tabular}{cccc}
\hline & \multicolumn{3}{c}{$\begin{array}{c}\text { (a) Number of fruits / plant (calculated on the basis of } \\
\text { the ratio yield/mean fruit mass) }\end{array}$} \\
\cline { 2 - 4 } & $\mathrm{T} 1(0+0)$ & $\mathrm{T} 2(30+30)$ & $\mathrm{T} 3(0+30)$ \\
\hline Achefri & $130.7 \pm 4.5$ & $141.9 \pm 4.5$ & $125.6 \pm 4.3$ \\
Aissa & $99.3 \pm 4$ & $86.9 \pm 4.3$ & $82.6 \pm 4.3$ \\
Moussa & $101.5 \pm 7$ & $73.3 \pm 6$ & $83.2 \pm 7.5$ \\
\hline
\end{tabular}

(b) Number of fruits observed on 10 cladodes

\begin{tabular}{cccc}
\cline { 2 - 4 } & $\mathrm{T} 1(0+0)$ & $\mathrm{T} 2(30+30)$ & $\mathrm{T} 3(0+30)$ \\
\cline { 2 - 4 } Achefri & $75.4 \pm 11.5$ & $117.0 \pm 12$ & $94.9 \pm 12$ \\
Aissa & $67.4 \pm 2.2$ & $61.7 \pm 2$ & $61.9 \pm 2$ \\
Moussa & $59.7 \pm 3.5$ & $70.7 \pm 3$ & $65.3 \pm 2$ \\
\hline
\end{tabular}

Table 5: Effect of irrigation dose T1: not irrigated, T2: $60 \mathrm{~mm}$ during flowering and $60 \mathrm{~mm}$ during fruit growth and T3: $60 \mathrm{~mm}$ only during fruit growth on the fruit yield of the varieties Achefri, Aissa and Moussa in 2012.

\begin{tabular}{ccccc}
\hline & \multicolumn{4}{c}{${\text { Fruit yield }\left(\mathrm{kg} \mathrm{plant}^{-1}\right)}$} \\
\cline { 2 - 5 } Variety & $\mathrm{T} 1$ & $\mathrm{~T} 2$ & $\mathrm{~T} 3$ \\
& Not irrigated & $\begin{array}{c}60 \mathrm{~mm}+60 \\
\mathrm{~mm}\end{array}$ & $0 \mathrm{~mm}+60 \mathrm{~mm}$ & \\
\hline Achefri & $20.4 \pm 0.8 \mathrm{a}$ & $26.4 \pm 0.7 \mathrm{~b}$ & $33.2 \pm 0.7 \mathrm{c}$ & $* *$ \\
Aissa & $17.7 \pm 0.5 \mathrm{a}$ & $23.5 \pm 0.5 \mathrm{~b}$ & $27.4 \pm 0.6 \mathrm{c}$ & $* \star$ \\
Moussa & $18.3 \pm 0.4 \mathrm{a}$ & $24.6 \pm 0.3 \mathrm{c}$ & $21.5 \pm 0.3 \mathrm{~b}$ & $* *$ \\
& $* *$ & $* *$ & $* *$ & \\
\hline
\end{tabular}

**: significant difference at $p \leq 0.01$

For a variety, different letters $a, b, c$ indicate significant differences

Fruit and pulp mass and the content of fruit in pulp were not significantly different according to treatments of irrigation as well as fruit length and diameter (Table 3). All these features only differed according to variety, except for the pulp/fruit ratio, which was remarkably constant between $52-55 \%$.

The numbers of fruits calculated (a) or observed (b) (Table 4 ) are highly correlated between them $\left(R^{2}=0.792\right)$ and are also significantly correlated with the yields (resp. $R^{2}(\mathrm{a})=0.976$ and $\left.R^{2}(\mathrm{~b})=0.836\right)$

\subsubsection{Effects of irrigation treatments on fruit yield and fruit quality in the second year's experiments}

Statistical analysis of yields revealed a significant interaction between the factors variety and treatments of irrigation. Results (Table 5) must be considered separately for each variety. For 'Achefri', the application of both $\mathrm{T} 2$ and $\mathrm{T} 3$ irrigations caused a very significant increase in the yields by 6 and $13 \mathrm{~kg} \mathrm{plant}^{-1}$ (or 30\% and 65\%), respectively. For the variety 'Aïssa', irrigations T2 and T3 increased the yields by nearly 6 and $10 \mathrm{~kg} \mathrm{plant}^{-1}$ (or $30 \%$ and $55 \%)$ respectively. For 'Moussa', irrigations significantly increased the yield by 6.3 and $3.2 \mathrm{~kg}$ plant $^{-1}$.

On 'Aissa' and 'Achefri', irrigation schedule T3 with $60 \mathrm{~mm}$ applied at the start of the ripening stage has given higher yields than T2 with $120 \mathrm{~mm}(60 \mathrm{~mm}$ during flowering and $60 \mathrm{~mm}$ during fruit growth), indicating that_irrigation during flowering and fruit growth had less positive effect than irrigation at the start of ripening stage_ Conversely, for 'Moussa' irrigating during flowering and fruit growth had positive effect on fruit growth. Fruit and pulp mass (Table 6) very significantly increased in the irrigated treatments (with the exception of the 'Moussa' pulp mass). The irrigations also increased the fruit length and diameter and reduced the 'pulp/fruit' ratio for 'Achefri' ( 55 vs. $58 \%$ ) and for 'Moussa' (52 vs. $59 \%)$. Yields and mean fruit mass were positively correlated $\left(R^{2}=0.802\right)$. 
Table 6: Effect of irrigation treatments (T1: not irrigated; T2: $60 \mathrm{~mm}$ during flowering and $60 \mathrm{~mm}$ during fruit growth; T3: $60 \mathrm{~mm}$ only during fruit growth) on fruit and pulp mass of the varieties 'Achefri', 'Aissa' and 'Moussa' in 2012.

\begin{tabular}{|c|c|c|c|c|c|c|c|c|c|c|c|c|c|c|c|c|c|c|c|}
\hline \multirow{2}{*}{ Variety } & \multicolumn{4}{|c|}{ Fruit mass (g) } & \multicolumn{4}{|c|}{ Pulp mass (g) } & \multicolumn{3}{|c|}{$\begin{array}{l}\text { Ratio Pulp/ } \\
\text { Fruit (\%) }\end{array}$} & \multicolumn{4}{|c|}{ Fruit length $(\mathrm{cm})$} & \multicolumn{4}{|c|}{ Fruit diameter $(\mathrm{cm})$} \\
\hline & $\mathrm{T} 1$ & $\mathrm{~T} 2$ & $\mathrm{~T} 3$ & & $\mathrm{~T} 1$ & $\mathrm{~T} 2$ & $\mathrm{~T} 3$ & & $\mathrm{~T} 1$ & $\mathrm{~T} 2$ & T3 & $\mathrm{T} 1$ & $\mathrm{~T} 2$ & $\mathrm{~T} 3$ & & $\mathrm{~T} 1$ & $\mathrm{~T} 2$ & $\mathrm{~T} 3$ & \\
\hline Achefri & 115 & 143 & 143 & ** & 66 & 76 & 79 & ** & 58 & 53 & 55 & 7.4 & 8.0 & 7.9 & * & 4.8 & 5.2 & 5.3 & ** \\
\hline Aissa & 122 & 141 & 142 & $* *$ & 67 & 72 & 79 & ** & 55 & 51 & 56 & 7.3 & 7.7 & 7.8 & * & 5.0 & 5.3 & 5.2 & * \\
\hline Moussa & 117 & 136 & 135 & ** & 69 & 70 & 71 & ns & 59 & 52 & 52 & 7.5 & 7.8 & 7.7 & * & 5.0 & 5.1 & 5.2 & ns \\
\hline
\end{tabular}

${ }^{\star}$ : significant difference $(p \leq 0.05) ;{ }^{* *}$ : very significant difference $(p \leq 0.01)$; ns: no significant difference.

Table 7: Effect of irrigation treatments T1: not irrigated, T2: $60 \mathrm{~mm}$ during flowering and $60 \mathrm{~mm}$ during fruit growth and T3: 60 $\mathrm{mm}$ only during fruit growth on the number of fruits produced per plant and by 10 cladodes in 2012 .

(a) Number of fruits /plant (calculated on the basis of the ratio yield/mean fruit

Variety mass)

\begin{tabular}{cccc}
\cline { 2 - 4 } & $\mathrm{T} 10 \mathrm{~mm}+0 \mathrm{~mm}$ & $\mathrm{~T} 260 \mathrm{~mm}+60 \mathrm{~mm}$ & $\mathrm{~T} 30 \mathrm{~mm}+60 \mathrm{~mm}$ \\
\hline Achefri & $178 \pm 12$ & $184 \pm 16$ & $232 \pm 18$ \\
Aissa & $145 \pm 10$ & $167 \pm 11$ & $193 \pm 14$ \\
Moussa & $157 \pm 3$ & $180 \pm 8$ & $159 \pm 6$ \\
\hline
\end{tabular}

(b) Number of fruits observed on 10 cladodes

\begin{tabular}{cccc} 
Variety & \multicolumn{3}{c}{ T2 $60+60$} \\
\cline { 2 - 4 } Achefri & $76.0 \pm 6.0$ & $82.0 \pm 8.0$ & $\mathrm{~T} 30+60$ \\
\cline { 2 - 4 } Aissa & $75.3 \pm 5.0$ & $92.5 \pm 6.5$ & $99.5 \pm 6.0$ \\
Moussa & $75.0 \pm 5.0$ & $87.5 \pm 4.0$ & $95.0 \pm 6.0$ \\
\hline
\end{tabular}

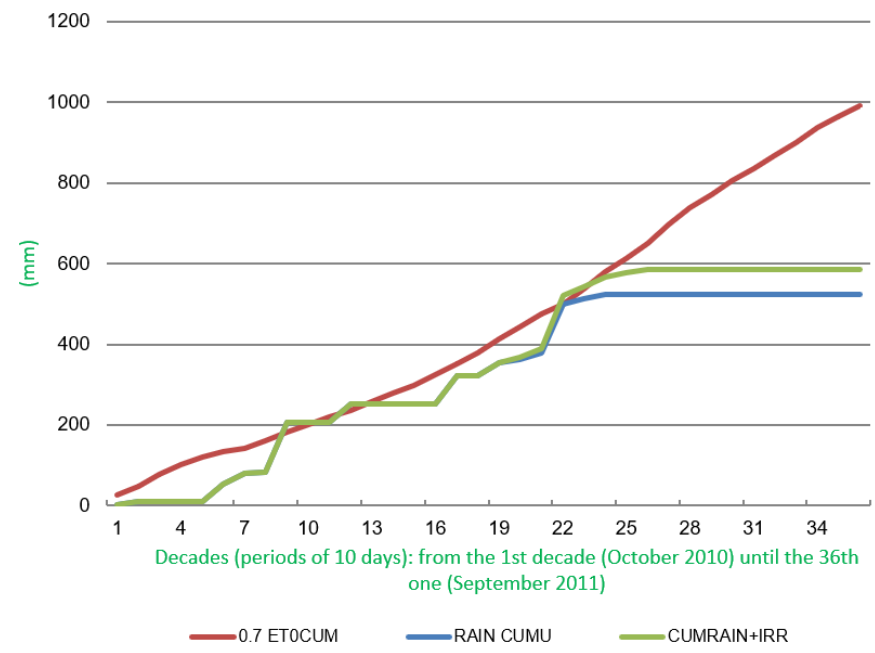

Figure 5: Hydric values (in $\mathrm{mm}$ ) on the basis of $\mathrm{Kc}=0.7$ and taking into account rainfall and irrigation. Agadir area, 2010-2011 season. (RAIN CUMU = cumulative rainfall; CUMRAIN+IRR = cumulative rainfall + irrigation). 


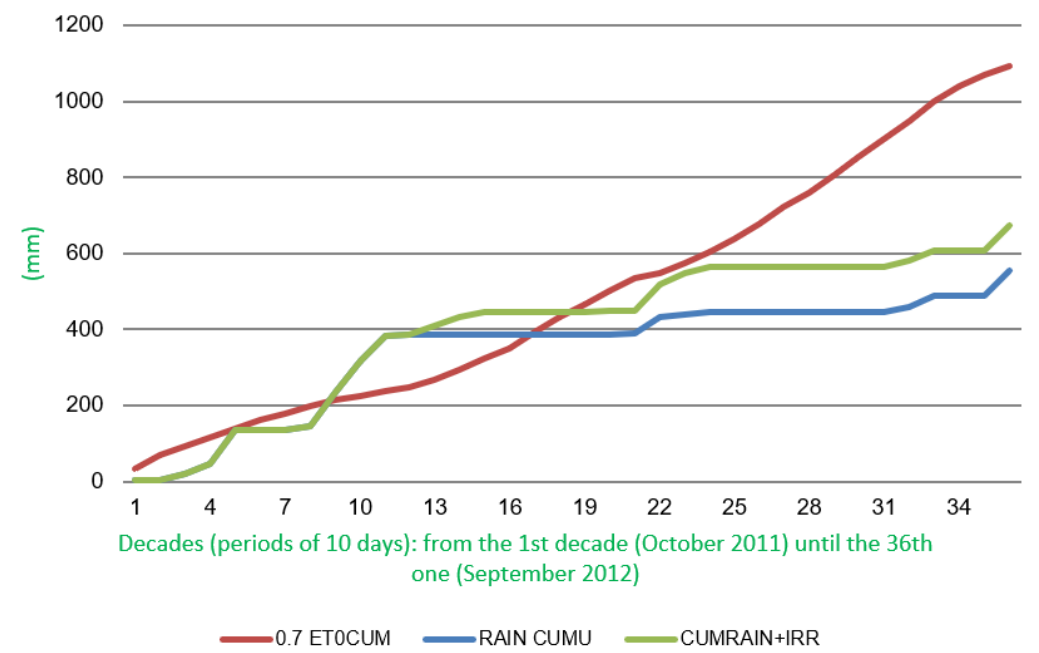

Figure 6: Hydric values (in $\mathrm{mm}$ ) on the basis of $\mathrm{Kc}=0.7$ and taking in account rainfall and irrigation. Agadir area, 2011-2012 season. (RAIN CUMU = cumulative rainfall; CUMRAIN + IRR = cumulative rainfall + irrigation).

Table 8: Effect of irrigation treatments (T1: not irrigated; T2: 30 or $60 \mathrm{~mm}$ during flowering and 30 or $60 \mathrm{~mm}$ during fruit growth; T3: 30 or $60 \mathrm{~mm}$ only during fruit growth) on fruit organoleptic characteristics of the varieties 'Achefri', 'Aissa' and 'Moussa' for 2011 and 2012.

\begin{tabular}{|c|c|c|c|c|c|c|c|c|c|c|}
\hline \multirow{2}{*}{\multicolumn{2}{|c|}{ Organoleptic Compounds }} & \multicolumn{3}{|c|}{ 'Achefri' } & \multicolumn{3}{|c|}{ 'Moussa' } & \multicolumn{3}{|c|}{ 'Aissa' } \\
\hline & & $\mathrm{T} 1$ & $\mathrm{~T} 2$ & $\mathrm{~T} 3$ & $\mathrm{~T} 1$ & $\mathrm{~T} 2$ & $\mathrm{~T} 3$ & $\mathrm{~T} 1$ & $\mathrm{~T} 2$ & $\mathrm{~T} 3$ \\
\hline \multirow{2}{*}{ The rate of juice (\%) } & 2011 & 71.23 & 69.06 & 72.18 & 71.14 & 69.61 & 70.35 & 70.44 & 71.44 & 71.45 \\
\hline & 2012 & 63.85 & 72.16 & 67.04 & 63.85 & 70.84 & 67.20 & - & - & - \\
\hline \multirow{2}{*}{ Total sugars (\%) } & 2011 & 48.49 & 49.26 & 54.55 & 67.05 & 56.78 & 55.86 & 52.47 & 51.87 & 56.56 \\
\hline & 2012 & 63.68 & 44.06 & 57.99 & 62.33 & 61.70 & 59.46 & - & - & - \\
\hline \multirow{2}{*}{$\begin{array}{c}\text { Titrable acidity } \\
\left(\mathrm{g}^{-1}\right)\end{array}$} & 2011 & 0.51 & 0.63 & 0.41 & 0.54 & 0.45 & 0.57 & 0.61 & 0.68 & 0.71 \\
\hline & 2012 & 0.69 & 0.45 & 0.50 & 0.85 & 0.78 & 0.68 & - & - & - \\
\hline \multirow{2}{*}{$\begin{array}{l}\text { Dry matter of the } \\
\text { juice (\%) }\end{array}$} & 2011 & 4.36 & 4.38 & 4.49 & 4.35 & 4.41 & 4.12 & 4.35 & 4.42 & - \\
\hline & 2012 & 4.46 & 4.43 & 4.40 & 4.38 & 4.36 & 4.37 & - & - & - \\
\hline \multirow{2}{*}{${ }^{\circ}$ Brix } & 2011 & 13.90 & 13.36 & 14.04 & 13.98 & 13.40 & 14.06 & 13.40 & 13.90 & 14.26 \\
\hline & 2012 & 14.43 & 12.40 & 12.85 & 14.20 & 13.06 & 14.43 & - & - & - \\
\hline \multirow[b]{2}{*}{$\mathrm{pH}$} & 2011 & 6.21 & 5.96 & 6.19 & - & 6.12 & - & 6.10 & 5.89 & 6.19 \\
\hline & 2012 & 6.03 & 5.99 & 6.10 & 6.13 & 5.67 & 5.99 & - & - & - \\
\hline
\end{tabular}

Although the number of fruits produced by 10 cladodes (observed) and per plant (computed) (Table 7) were not significantly correlated $\left(R^{2}=0.409\right)$, the means indicate that the T3 treatment increased the number of fruits more than the T2 treatment at 'Aissa' and 'Achefri' varieties. Therefore, for 'Moussa' variety the number of fruits produced per plant was higher in T2 than in T3. Yield variations are well explained by the number of fruits per plant (coefficient of determination $89 \%$ ) and poorly by the numbers of fruits observed on ten cladodes (coefficient of determination $38 \%$ ), illustrating the difficulties of constituting representative samples.

\subsubsection{Relations between the two seasons yield and cli-} matic conditions

Referring to the climatic data (Figure 3), the results indicate a link between fruit yield and climatic conditions during the growing season, as well as with the supplemental irrigation timing. Figures 5 and 6 display the cumulated ETR $\left(=0.7 * \mathrm{ET}_{0}\right)$, the cumulated rainfall and the cumulated rainfall + irrigation for the first year and second year experiments. 


\subsubsection{Effects of irrigation treatments on the fruit qual-} ity in the $1^{\text {st }}$ year and $2^{\text {nd }}$ year's experiments

In 2011, irrigation treatments did not significantly modify the qualitative components of the fruit and the juice. In the second year experiments, the amount of juice in fruit was higher in irrigated treatments; the content of total sugars and the titratable acidity of fruit were lower. Brix value and $\mathrm{pH}$ of fruit juice were not affected by the irrigation regime (Table 8 ).

\subsection{DISCUSSION}

Our results are globally consistent with those obtained by Van Der Merwe et al. (1997) in South Africa, and by Gugliuzza et al. (2002) and Mulas \& D'hallewin (1997) in Italy. But they clearly illustrate the negative effects of irrigations applied when the rainfall is sufficient in relation to the variety's water demand. Zegbe and Sevin-Palestina (2020) who studied the effect of supplemental irrigation (SI) (application of irrigation to reach field capacity every time soil water content was close to or around permanent wilting point) and full irrigation (FI) (application of irrigation weekly to reach field capacity) on fruit yield and quality of four cactus pear varieties in Mexico, also reported that fruit yield and fruit size in terms of fruit diameter and fruit mass were higher in SI and FI irrigated plants than in not irrigated plants under rainfed conditions (NI). Fruit yield was similar in irrigated SI and FI plants during the first two growing seasons, but in the third growing season fruit yield was higher in SI plants than in FI plants. Supplemental irrigation has also enhanced fruit yield and quality of fruit trees, such as peaches and olives (Oweis \& Hachum, 2012; Razouk et al., 2013).

Considering that the aim was not an extensive study of the hydrous relationships, and accepting the approximations, it can be observed that on these bases, the periods of significant risk of water stress without irrigation were as follows: (i) in the season 2010/2011, the period starting from the third decade of May (decade 23) to the end of the cycle; (ii) in the season 2011/2012, the period starting from the first decade of April (decade 17), whereas the period between the end of December and the end of March showed a positive water supply for the cactus. This clearly explains the differences between the irrigation efficiencies in the first season and in the second season of trials. As water for irrigation is scare in arid and semi-arid areas, it's important to explore the saving water strategies and supplemental irrigation during critical crop stages, such as the period of flowering and fruit growth, could be one such strategy (Oweis \& Hachum, 2012; Zegbe \& Sevin-Palestina, 2020). Supplemental irrigation is a feasible irrigation for cactus pear in areas where water availability is limited for agricultural activities. It saved water by $51-52 \%$ and reduced crop water use by $38-42 \%$, in comparison to full irrigation (Zegbe \& Sevin-Palestina, 2020).

The results regarding fruit quality were similar to those reported in Italy where an application of a micro spray irrigation of $60 \mathrm{~mm}$ in three applications (the first one week before flowering, the second two weeks after flowering and the third six weeks after flowering) on a 10-year old plantation of O. ficus-indica (L.) Mill. had a positive effect on fruit size and no significant effect on the organoleptic properties ( ${ }^{\circ} \mathrm{Brix}, \mathrm{pH}$, malic acid) (Gugliuzza et al., 2002). In the same country, during three consecutive years, a drip irrigation of $566 \mathrm{~m}^{3} \mathrm{ha}^{-1}$ per year applied from May to September to adult plantations of four varieties of Opuntia increased yield by $40 \%$ to $50 \%$ for the first two years, and $130 \%$ in the third year (Mulas \& D'hallewin, 1997). In South Africa, a drip irrigation of $12.5 \mathrm{~mm}$ per week applied during the dry period (from 15 July to 15 February) on five varieties of $O$. ficus-indica increased fruit yield from 9.2 to $10.7 \mathrm{~kg} \mathrm{plant}^{-1}(+16 \%)$ and fruit and pulp mass by $6 \%$ and $3 \%$, respectively (Van Der Merwe et al., 1997). Zegbe and Sevin-Palestina (2020) also reported that supplemental irrigation plants maintained fruit yield, fruit mass and marketable fruit size at the level of full irrigation plants. The later authors indicated that supplemental irrigation could be a better irrigation strategy than full irrigation in areas where a drought period occurs during the fruit development period or during the whole growing season.

For the all varieties, fruits obtained in irrigated treatments have a medium calibre (121-150 g) (Chessa \& Nieddu, 1997) and meet the South African commercial criteria for their pulp/fruit ratio which is more than 50\% (De Wit et al., 2010). Despite no statistical significance, our results also illustrate that irrigation could possibly slightly affect the content of juice in the fruit, the content of sugar and the acidity of the juice.

\section{CONCLUSIONS}

From the results, it is obvious that the optimization of the irrigation in relation with yield and fruit physical properties (fruit mass and shape) must be considered for each individual variety and growth stage, and must take into account the climatic conditions notably the rainfall_or better the evapotranspiration_cumulated from the start of a productive cycle. The varieties Aissa and Moussa yielded less when irrigated in the first season, when obviously the climatic water supply was sufficient. They have responded very positively to irrigation in the second and dryer season. The variety Achefri responded 
positively in the first season and very positively in the second season, much better with one single irrigation in the fruit growing period than with two irrigations. This illustrates the limits of irrigation, and the disadvantage of over-irrigating. A simplified water status allows both delivering water as soon as needed and avoiding water excesses resulting in harmful effects to the crop. Considering the fruit chemical quality, all parameters measured did not vary in the function of the irrigation: irrigation did not decrease the quality. Another beneficial effect of irrigation is the intense increase of the shoot number emitted per cladode in the three varieties as reported in Arba et al. (2018).

\section{ACKNOWLEDGEMENTS}

The authors wish to thank the Belgian technical cooperation (BTC) and Agrotech Souss Massa Draa for their financial support and all the people who contributed to the realization of this study.

\section{REFERENCES}

Allen, R.G., Peirera, L.S., Raes, D.\& Smith, M. (1998). Crop evapotranspiration (Guidelines for computing crop water requirements). Rome: FAO irrigation and drainage paper,

Arba, M. (2009). Le cactus opuntia une espèce fruitière et fourragère pour une agriculture durable au Maroc. In A. Bouaziz, R. Choukr-Allah, R. Mrabet, \& A. Falisse (Eds.). Durabilité des systèmes de culture en zone méditerranéenne et gestion des ressources en eau et en sol (pp. 215-223). Rabat: Cana Print.

Arba, M., Falisse, A., Choukr-Allah, R. \& Sindic, M. (2018). Effects of irrigation at critical stages on the phenology of flowering and fruiting of the cactus Opuntia spp. Brazilian Journal of Biology, 78(4), 653-660. http://dx.doi. org/10.1590/1519-6984.170086

Chessa, I. \& Nieddu, G. (1997). Descriptors for cactus pear (Opuntia spp.). FAO Cactusnet Newsleter special issue. Sassari: Tipografia moderna.

Consoli, S., Inglese, G. \& Inglese, P. (2013). Determination of evapo-transpiration and annual biomass productivity of a cactus pear Opuntia ficus-indica (L.) Mill. orchard in a semi-arid environment. Journal of Irrigation and Drainage Engineering, 139(8), 680-690. https://doi.org/10.1061/ (ASCE)IR.19434774.0000589

De Wit, M., Nel, P., Osthooff, G.\& Labuschagne, M. T.(2010). The effect of variety and location on cactus pear (Opuntia ficus-indica) fruit quality. Plant Foods for Human Nutrition, 65(2), 136-145.https://doi.org/10.1007/s11130-010-0163-7

Felker, P. \& Inglese, P.(2003). Short-term and long-term research needs for Opuntia ficus indica (L.) Mill. utilization in arid areas. Journal of Professional Association for Cactus Development, 5,131-151.

Felker, P., Soulier,C., Leguizamon, G. \& Ochoa, J. (2002). A comparison of the fruit parameters of 12 Opuntia clones grown in Argentina and the United States. Journal of Arid Environments, 52(3), 361-370. https://doi.org/10.1006/ jare.2002.1001

Gugliuzza, G., Inglese, P. \& Farina, V. (2002). Relationship between fruit thinning and irrigation on determining fruit quality of cactus pear (Opuntia ficus-indica) fruits. Acta Horticulturae, 581, 205-209.https://doi.org/10.17660/ActaHortic.2002.581.20

Inglese, P. (2010). Cactus pear Opuntia ficus-indica (L.) Mill. for fruit production: An overview. Rome: FAO Cactusnet Newsletter special issue 12 .

Lazzara, P. \& Rana, G. (2010). The crop coefficient (Kc) values of the major crops grown under Mediterranean climate. Bari, via C. Ulpiani: CRA-Research Unit for Agricultural in Dry Environments.

Le Houérou, H.N. (2002). Cacti (Opuntia spp.) as a fodder crop for marginal lands in the Mediterranean basin. Acta Horticulturae,581, 21-46. https://doi.org/10.17660/ActaHortic.2002.581.1

Mulas, M. \& D’hallewin, G. (1997). Fruit quality of four cactus pear (Ountia ficus-indica Mill.) cultivars as influenced by irrigation. Acta Horticulturae, 438, 115-122. https://doi. org/10.17660/ActaHortic.1997.438.14

Nefzaoui, A. \& Bensalem, H. (2000). Opuntia: A strategic fodder and efficient tool to combat desertification in the WANA region. Rome: FAO Cactusnet Newsletter special issue.

Nobel, P.S.(2002). Cacti: Biology and uses. California: University of California press.

Nobel, P.S. \& Bobich, E.G.(2002). Environmental Biology. In P.S. Nobel (ed.). Cacti: Biology and uses (pp. 57-74). California: University of California press.

Oweis, T.\& Hachum, A. (2012). Supplemental irrigation, A Highly Efficient Water-use Practice. Aleppo, Syria: ICARDA.

Potgieter, J. and D'Aquino, S. (2017). Fruit production and post-harvest management. In P. Inglese, C. Mondragon, A. Nefzaoui \& C. Sáenz. (Eds.). Crop Ecology, Cultivation and Uses of Cactus Pear (pp.51-71). Rome, Italy: FAO \& ICARDA.

Razouk, R., Ibijbijen, J. \& Kajj, A. (2013). Optimal time of supplemental irrigation during fruit development of rainfed olive tree (Olea europaea'Picholine Marocaine') in Morocco. American Journal of ExperimentalAgriculture, 3(4), 685697. https://doi.org/10.9734/ajea/2013/3348

Van Der Merwe, L.L., Wessels, A. B. \& Ferreira, D. I. (1997). Supplementary irrigation for spineless cactus pear.Acta Horticulturae, 438, 77-82. https://doi.org/10.17660/ActaHortic.1997.438.9

Zegbe, J. A. \& Servín-Palestina M. (2020). Supplemental irrigation to save water while growing cactus pear in semi-arid regions. Irrigation and Drainage, 2020,1-12. https://doi. org/10.1002/ird.2542

Zegbe, J.A., Serna-Pérez, A. \& Maldonado-Rodríguez, M.R.(2019). Supplemental irrigation improves water-use efficiency, yield, and some fruit quality attributes of 'Dalia Roja' cactus pear. Acta Horticulturae, 1247, 245-249. https://doi.org/10.17660/ActaHortic.2019.1247.33

Zegbe, J.A. \& Serna-Pérez, A.(2018). Irrigation options to save water while enhancing export-size fruit and storability of 
'SmoothRed'cactus pear. Journal of the Science of Food and Agriculture, 98(14), 5503-5508. https://doi.org/10.1002/ jsfa.9096

Zegbe Dominguez, J.A., Serna Perez, A. \& Mena Covarrubias, J. (2015). Irrigation enhances postharvest performance of 'Cristalina' cactus pear fruit. Acta Horticulturae, 1067, 417422. https://doi.org/10.17660/ActaHortic.2015.1067.57 